\title{
Metabolic Disorders in Dairy Calves in Postpartum Period
}

\author{
A. PODHORSKÝ, A. PECHOVÁ, R. DVOŘÁK, L. PAVLATA \\ Clinic of Diseases of Ruminants, Faculty of Veterinary Medicine, University of Veterinary \\ and Pharmaceutical Sciences Brno, Czech Republic \\ Received September 22, 2005 \\ Accepted July 9, 2007
}

\begin{abstract}
Podhorský A., A. Pechová, R. Dvořák, L. Pavlata: Metabolic Disorders in Dairy Calves in Postpartum Period. Acta Vet. Brno 2007, 76: S45-S53.

The aim of this study was, in terms of analysis of causes of disorders in calves on dairy farms, to evaluate occurrence of metabolic disorders in their postnatal period. In 23 agricultural farms (14 farms with the incidence of clinical forms of disease in calves during milk nutrition period - group D; 9 farms with no clinical disease - group H) clinical examination was performed, blood samples were collected and data concerning the provision of permanent day and night care for calves (PDC) during delivery and in early postpartum period were collected. The samples were taken from 3 - 5 calves in every farm (totally 97, H - 38, D - 59). Biochemical indicators that have some relations to the quality of colostral nutrition were determined (the concentrations of immunoglobulins - Ig, total protein - TP, albumin - A, globulins - G, vitamin E and A, the activity of gammaglutamyl transferase - GMT) and to the microelement metabolism (the activities of glutathione peroxidase - GSH-Px for evaluation of selenium ( $\mathrm{Se})$ status, the concentrations of copper $(\mathrm{Cu})$ and zinc $(\mathrm{Zn})$ ). While evaluating the entire group of examined calves, we found a high occurrence of metabolic disorders in calves connected with colostral nutrition and also high occurrence of microelement deficiencies. The decrease in TP was diagnosed in $80 \%$, the decrease in $\mathrm{G}$ in $78 \%$, the decrease in concentration of $\mathrm{Ig}$ in $78 \%$ and $74 \%$ of calves had higher A/G ratio. Insufficient intake of colostrum showed also lower activities of GMT in 76\% of calves. Hypovitaminosis $\mathrm{E}$ was diagnosed in $67 \%$ of calves and hypovitaminosis A in $19 \%$ of calves. Microelement deficiencies were found in $77 \%(\mathrm{Cu}), 39 \%(\mathrm{Se})$, and $10 \%(\mathrm{Zn})$ of calves. While comparing the results for calves in groups $\mathrm{H}$ and $\mathrm{D}$, in the group of calves from farms with no clinical disease $(\mathrm{H})$ a significantly higher $(p<0.01)$ concentrations of albumin and vitamin $\mathrm{E}$, as well as vitamin $\mathrm{A}(p<0.05)$ were established. When comparing the farms with provided daylong care $(\mathrm{PDC}+)$ and with no daylong care $(\mathrm{PDC}-)$, in $\mathrm{PDC}+$ farms calves had a significantly higher $(p<0.01)$ concentration of TP and G, GSH-Px activity, and also a significantly lower $(p<0.01) \mathrm{A} / \mathrm{G}$ ratio, which proves a higher-quality colostral nutrition. The results thus prove that the incidence of metabolic disorders in dairy calves in the Czech Republic represents a highly actual problem and that one of the significant factors that influence this condition is the insufficient care for and the related insufficient colostral nutrition of the calves.
\end{abstract}

Cattle, colostral nutrition, biochemical indicators, trace elements, immunoglobulins

The calf metabolism is affected by nutrition and thus also by the pregnant cow metabolism and in the early postnatal period mainly by means of colostrum intake. Colostrum is a source of nutrition to a calf in an optimum ratio with respect to the development of digestion and it is an important stimulator of the gastrointestinal tract activity. It also provides newborn calves not only with basic nutrition but also with immunoglobulins, a high volume of vitamins (mostly soluble in fat), minerals and also a series of unspecified antibacterial factors (interferon, lactoperoxidase, lactoferrin) and cells that strengthen in various ways the defence functions of the newborn (Campana and Baumrucker 1995; Blum and Hammon 2000). In calves, it is important to intake a satisfactory volume of colostrum of a high quality that is determined by the amount of

Address for correspondence:

Doc. MVDr. Leoš Pavlata, Ph.D.

Clinic of Diseases of Ruminants

Faculty of Veterinary Medicine

University of Veterinary and Pharmaceutical Sciences Brno

Palackého 1-3, 61242 Brno

Czech Republic

Phone: +420541562407

Fax: +420 541562407

E-mail: pavlatal@vfu.cz

http://www.vfu.cz/acta-vet/actavet.htm 
immunoglobulins to a large degree. Any failure of colostral nutrition results in a deficiency of the adequate immunoglobulin concentration in the blood plasma of the calves and thus also a greater susceptibility to diseases since no sufficient passive immunity has been established. The most common clinical forms of calf illnesses from insufficient colostral nutrition are septicaemia and diarrhoea. Colostral intake in a calf leads to a change of a series of biochemical indicators (Rauprich et al. 2000; Pavlata et al. 2004a) with whose monitoring colostral nutrition checks can be carried out.

Also in the cases of vitamin and mineral insufficiencies, metabolic process and immune function disorders occur. Their manifestations are by vast majority non-specific and they display themselves clinically mainly by an increased susceptibility to infectious diseases. As opposed to vitamins (mostly fat-soluble), a majority of minerals easily pass through the placenta into the foetal blood, or the developing foetus is even capable of utilizing minerals present in the blood of its dam, even at her own expense. The supply status in a calf organism after the birth is thus greatly determined by the supply status of the dam in pregnancy. Colostrum is also another important source of minerals (Abdelrahman and Kincaid 1993; Hostetler et al. 2003; Pavlata et al. 2004b).

With respect to the above mentioned information, when performing the diagnostic of the increased disease ratio in calves, one must pay attention chiefly to the colostral nutrition checks by blood analysis and also to the microelement and vitamin profile of the calves. The aim of this study was to assess the occurrence of the above mentioned calf metabolic disorders in the milk nutrition period in calves coming from farms with no clinical disease and from farms with increased incidence of the disease, and to evaluate the results depending (among other factors) on whether the calves came from farms with or without provided permanent day and night care.

\section{Materials and Methods}

In 23 agricultural farms (14 farms with the occurrence of clinical forms of disease in calves during milk nutrition period - diarrhea, respiration syndrome, umbilical diseases, increased percentage of death losses group D, and 9 farms with no clinical disease (group $\mathrm{H}$ ) where we carried out preventive diagnostics of subclinical metabolic disorders in calves), a basic evaluation of the housing system, provision of permanent day and night care during calf deliveries and in the first hours after the delivery, and also evaluation of methods of delivery management and postpartum treatment of calves and colostral nutrition provision. All farmers from 23 agricultural farms mentioned that colostral nutrition of calves was without problems and that they had controlled individual colostrum feeding.

A basic clinical examination of calves was performed and samples for laboratory tests were taken (Table 1). The examination was carried out from autumn 2003 to spring 2004.

The samples were always collected from 3 - 5 calves of the analysed herd. Calves at the age of 1 - 7 days were chosen for sampling in each farm. If there were on the farm more than five calves at appropriate age (up to 7 days) the selection was performed accidentally.

In all of them, indicators regarding the quality of colostral nutrition were assessed in the laboratory: total protein content (TP), albumin (A), globulin (G), immunoglobulin (Ig), vitamin E and A contents and the activity of gamma glutamyl transferase (GMT) and those evaluating microelement metabolism (the activity of GSHPx in whole blood for the assessment of selenium status in the animals, copper and zinc concentration in the serum). All of the biochemical examinations were carried out in a clinical biochemistry laboratory of our clinic. Zinc and copper were determined in a serum sample by the flame AAS technique. The catalytic activity of the GMT, GSH-Px, the concentrations of TP and albumin were determined using an automated analyser Cobas Mira by standardised photometric methods using the tests suplied by Lachema (GMT KIN 100 catalogue No. 1302082), Randox (RANSEL Glutathione Peroxidase), BioVendor ('Protein celkový catalogue No. 12751) and Human (ALBUMIN liquicolor catalogue No. 10560). The globulin (G) value and the A/G ratio were calculated from the TP and A. Vitamin E was determined by a fluorometric method on a 204 Perkin - Elmer fluorescence spectrophotometer (Bouda et al. 1980). Immunoglobulins were determined using the zinc sulphate turbidity test (Slanina et al. 1976).

Based on the results, the incidence of metabolic disorders in individual farms and in the entire group of examined calves was established. We also compared results between calves coming from farms with the incidence of clinical symptoms of the disease (D) and calves from farms with no clinical disease (H), as well as results between farms with declared permanent day and night care (PDC) and farms without the PDC. The attendants were present on the PDC farms during whole $24 \mathrm{~h}$ every day, but on the other farms the attendants were present 
Table 1. List of investigated farms, including characteristics of housing systems, provision of permanent day and night care (PDC) and medical history. (OIH - outside individual hutches, RS - respiratory syndrome, $\mathrm{H}$ - Holstein cattle, $\mathrm{CPC}$ - Czech Pied cattle, $\mathrm{CaH}$ - calving house)

\begin{tabular}{|c|c|c|c|c|c|c|}
\hline Farm & $\begin{array}{l}\text { Number } \\
\text { of dairy } \\
\text { cows in } \\
\text { farm }\end{array}$ & Breed & Housing during delivery & Calf housing & PDC & Medical history \\
\hline 1 & 180 & $\mathrm{H}$ & Stanchion housing & Cages for calves & + & $\begin{array}{c}\text { RS, diarrhea, umbilical } \\
\text { inflammations }\end{array}$ \\
\hline 2 & 96 & $\mathrm{CPC}$ & Stanchion housing & Stanchion housing & + & RS, joint deformities \\
\hline 3 & 176 & $\mathrm{CPC}$ & Stanchion housing & $\mathrm{OIH}$ & + & Good clinical health \\
\hline 4 & 96 & $\mathrm{CPC}$ & Stanchion housing & $\mathrm{OIH}$ & + & Good clinical health \\
\hline 5 & 96 & $\mathrm{CPC}$ & $\mathrm{CaH}$ - group box & $\mathrm{OIH}$ & - & Diarrhea \\
\hline 6 & 380 & $\mathrm{H}$ & $\mathrm{CaH}$ - group box & $\begin{array}{l}\text { Individual pens } \\
\text { in a separate unit }\end{array}$ & - & Good clinical health \\
\hline 7 & 180 & $\mathrm{H}$ & $\mathrm{CaH}$ - group box & $\mathrm{OIH}$ & + & Good clinical health \\
\hline 8 & 176 & $\mathrm{CPC}$ & $\mathrm{CaH}$ - group box & $\mathrm{OIH}$ & + & Good clinical health \\
\hline 9 & 320 & $\mathrm{H}$ & $\mathrm{CaH}$ - group box & $\mathrm{OIH}$ & - & Good clinical health \\
\hline 10 & 300 & $\mathrm{H}$ & $\mathrm{CaH}$ - group box & $\mathrm{OIH}$ & - & Diarrhea, skin problems \\
\hline 11 & 500 & $\mathrm{H}$ & $\mathrm{CaH}$ - group box & $\mathrm{OIH}$ & - & Diarrhea \\
\hline 12 & 320 & $\mathrm{H}$ & $\mathrm{CaH}$ - group box & $\mathrm{OIH}$ & - & Diarrhea, RS \\
\hline 13 & 400 & $\mathrm{H}$ & $\mathrm{CaH}$ - group box & $\mathrm{OIH}$ & - & $\begin{array}{c}\text { Calf stillbirth, joint } \\
\text { deformities, } \\
\text { diarrhea, RS }\end{array}$ \\
\hline 14 & 440 & $\mathrm{H}$ & Stanchion housing & Stanchion housing & + & $\begin{array}{l}\text { RS, umbilical } \\
\text { inflammations }\end{array}$ \\
\hline 15 & 500 & $\mathrm{H}$ & $\mathrm{CaH}$ - group box & $\mathrm{OIH}$ & - & Diarrhea \\
\hline 16 & 300 & $\mathrm{H}$ & $\mathrm{CaH}$ - group box & $\mathrm{OIH}$ & - & Good clinical health \\
\hline 17 & 300 & $\mathrm{H}$ & $\mathrm{CaH}$ - group box & $\mathrm{OIH}$ & - & Good clinical health \\
\hline 18 & 180 & $\mathrm{H}$ & Stanchion housing & $\begin{array}{l}\text { In group pens } \\
\text { in the unit }\end{array}$ & - & RS, diarrhea \\
\hline 19 & 180 & $\mathrm{H}$ & $\mathrm{CaH}$ - group box & $\mathrm{OIH}$ & - & Good clinical health \\
\hline 20 & 420 & $\mathrm{CPC}$ & $\mathrm{CaH}$ - group box & $\mathrm{OIH}$ & - & $\begin{array}{c}\text { Acute death, diarrhea, } \\
\text { lying down }\end{array}$ \\
\hline 21 & 450 & $\mathrm{H}$ & $\mathrm{CaH}$ - group box & $\mathrm{OIH}$ & + & $\mathrm{RS}$ \\
\hline 22 & 400 & $\mathrm{H}$ & $\mathrm{CaH}$ - group box & $\mathrm{OIH}$ & - & $\begin{array}{c}\text { Bone deformities, } \\
\text { cachexia, umbilical } \\
\text { inflammation, high } \\
\text { death rate }\end{array}$ \\
\hline 23 & 400 & $\mathrm{CPC}$ & $\mathrm{CaH}$ - group box & $\begin{array}{l}\text { In group pens in } \\
\text { the unit }\end{array}$ & + & $\begin{array}{l}\text { RS, diarrhea, high } \\
\text { death rate }\end{array}$ \\
\hline
\end{tabular}

only from 4:00 h to 21:00 h. If the delivery was between 21:00 h and 4:00 h, the interval between the delivery and control of individual colostrum feeding could be higher than the recommended 2 - 3 hours.

Basic statistical parameters of results (means, standard deviations) in individual groups, and a comparison between results of groups (using Student's $t$-test after F-test for equality of variations) were carried out using the Microsoft Excel XP software.

\section{Results and Discussion}

The basic statistical characteristics of the monitored biochemical indicators in the blood of calves under study are presented in Tables 2 and 3 . 
Table 2. The basic statistical characteristics of the value sets of the biochemical monitoring concerning colostral nutrition of the calves $(\mathrm{n}=97)$

\begin{tabular}{|l|c|c|c|c|c|c|c|c|c|}
\hline & $\begin{array}{c}\mathrm{TP} \\
\mathrm{g} \cdot \mathrm{l}^{-1}\end{array}$ & $\begin{array}{c}\mathrm{A} \\
\mathrm{g} \cdot \mathrm{l}^{-1}\end{array}$ & $\begin{array}{c}\mathrm{G} \\
\mathrm{g} \cdot \mathrm{l}^{-1}\end{array}$ & $\mathrm{~A} / \mathrm{G}$ ratio & $\begin{array}{c}\text { GMT } \\
\mu \mathrm{kat} \cdot \mathrm{l}^{-1}\end{array}$ & $\begin{array}{c}\text { Vit. A } \\
\mu \mathrm{mol} \cdot \mathrm{l}^{-1}\end{array}$ & $\begin{array}{c}\text { Vit. E } \\
\mu \mathrm{mol} \cdot \mathrm{l}^{-1}\end{array}$ & $\begin{array}{c}\text { Ig } \\
\mathrm{U} \text { ZST }\end{array}$ & $\begin{array}{c}\text { Age } \\
\text { days }\end{array}$ \\
\hline Mean & 53.63 & 30.04 & 23.61 & 1.44 & 8.95 & 1.15 & 4.41 & 8.20 & 4.02 \\
\hline S.D. & 7.89 & 2.88 & 8.21 & 0.55 & 14.26 & 0.48 & 2.62 & 5.12 & 2.02 \\
\hline Min. & 40.70 & 22.1 & 8.20 & 0.55 & 0.14 & 0.18 & 0.88 & 0.60 & 1 \\
\hline Max. & 75.40 & 36.5 & 46.20 & 3.96 & 73.04 & 2.70 & 14.13 & 22.98 & 7 \\
\hline V $\%$ & 14.67 & 9.60 & 34.77 & 37.99 & 159.35 & 41.45 & 59.46 & 62.36 & 50.25 \\
\hline
\end{tabular}

Table 3. The basic statistical characteristics of the value sets involved in the microelement profiles of the calves $(\mathrm{n}=97)$

\begin{tabular}{|c|c|c|c|}
\hline & $\begin{array}{c}\mathrm{Zn} \\
\mu \mathrm{mol} \cdot \mathrm{r}^{-1}\end{array}$ & $\begin{array}{c}\mathrm{Cu} \\
\mu \mathrm{mol} \cdot \mathrm{l}^{-1}\end{array}$ & $\begin{array}{c}\text { GSH-Px } \\
\mu \mathrm{kat} \cdot \mathrm{l}^{-1}\end{array}$ \\
\hline Mean & 19.27 & 9.59 & 661.36 \\
\hline S.D. & 5.99 & 3.19 & 194.89 \\
\hline Min. & 5.46 & 4.37 & 286.50 \\
\hline Max. & 36.70 & 17.79 & 1199.00 \\
\hline V $\%$ & 31.11 & 33.27 & 29.47 \\
\hline
\end{tabular}

To evaluate the results of metabolic disorder occurrences (Tables 4 and 5), we used values provided by Hofírek et al. (1990), Slanina et al. (1991), Pavlata et al. (2000, 2003a), Kraft and Dürr (2001) and by our laboratory. The results of the assessment of the occurrences of changes in biochemical indicators concerning protein metabolism, vitamin profile and the activity of GMT are presented in Table 4. The results of the assessments of the occurrences of microelement deficiencies are presented in Table 5. The results are being assessed in individual animals but also with respect to the average concentrations in calves of the individual farms.

Table 4. The metabolic disorder incidence and its impact on the quality of colostral nutrition in calves (A - all calves; $\mathrm{H}$ - healthy calves; $\mathrm{D}$ - diseased calves)

\begin{tabular}{|c|c|c|c|c|c|c|c|c|c|}
\hline & group & $\begin{array}{c}\mathrm{TP} \\
<60 \\
\mathrm{~g} \cdot \mathrm{l}^{-1}\end{array}$ & $\begin{array}{l}\text { Alb. } \\
<28 \\
\mathrm{~g} \cdot \mathrm{l}^{-1}\end{array}$ & $\begin{array}{l}\text { Glob. } \\
<30 \\
\mathrm{~g} \cdot 1^{-1}\end{array}$ & $\begin{array}{c}\mathrm{A} / \mathrm{G} \\
>1\end{array}$ & $\begin{array}{c}\text { GMT } \\
<10 \\
\mu \mathrm{kat} \cdot \cdot^{-1}\end{array}$ & $\begin{array}{c}\text { Vit. A } \\
<0.7 \\
\mu \mathrm{mol} \cdot{ }^{-1}\end{array}$ & $\begin{array}{c}\text { Vit. E } \\
<4.64 \\
\mu \mathrm{mol} \cdot{ }^{-1}\end{array}$ & $\begin{array}{c}\text { Ig } \\
<12 \\
\text { U ZST }\end{array}$ \\
\hline \multirow{3}{*}{$\begin{array}{l}\text { Number } \\
/ \% \text { of } \\
\text { calves }\end{array}$} & $\mathrm{A}(\mathrm{n}=97)$ & $78 / 80$ & $20 / 21$ & $76 / 78$ & $72 / 74$ & $74 / 76$ & $18 / 19$ & $65 / 67$ & $76 / 78$ \\
\hline & $\mathrm{H}(\mathrm{n}=38)$ & $32 / 84$ & $5 / 13$ & $31 / 82$ & $29 / 76$ & $33 / 87$ & $3 / 8$ & $21 / 55$ & $33 / 87$ \\
\hline & $\mathrm{D}(\mathrm{n}=59)$ & $46 / 78$ & $15 / 25$ & $45 / 76$ & $45 / 76$ & $42 / 71$ & $15 / 25$ & $44 / 75$ & $43 / 73$ \\
\hline \multirow{3}{*}{$\begin{array}{l}\text { Number } \\
/ \% \text { of } \\
\text { farms }\end{array}$} & $\mathrm{A}(\mathrm{n}=23)$ & $21 / 91$ & $2 / 9$ & $22 / 96$ & $22 / 96$ & $16 / 70$ & $1 / 4$ & $14 / 61$ & $20 / 87$ \\
\hline & $\mathrm{H}(\mathrm{n}=9)$ & $8 / 89$ & $0 / 0$ & $9 / 100$ & $9 / 100$ & $9 / 100$ & $0 / 0$ & $4 / 44$ & $9 / 100$ \\
\hline & $\mathrm{D}(\mathrm{n}=14)$ & $13 / 93$ & $2 / 14$ & $13 / 93$ & $13 / 93$ & $7 / 50$ & $1 / 7$ & $10 / 71$ & $11 / 79$ \\
\hline
\end{tabular}

Table 5. Microelement deficiency incidence in the monitored calves (A - all calves; $\mathrm{H}$ - healthy; D - diseased)

\begin{tabular}{|c|c|c|c|c|}
\hline \multirow{2}{*}{ Group } & $\begin{array}{c}\mathrm{Zn} \\
<12 \mu \mathrm{mol} \cdot \mathrm{l}^{-1}\end{array}$ & $\begin{array}{c}\mathrm{Cu} \\
<12 \mu \mathrm{mol} \cdot 1^{-1}\end{array}$ & $\begin{array}{c}\text { Se }- \text { GSH-Px } \\
<600 \mu \mathrm{kat} \cdot \mathrm{l}^{-1}\end{array}$ \\
\hline \multirow{3}{*}{ Number/\% of calves } & $\mathrm{A}(\mathrm{n}=79)$ & $8 / 10$ & $61 / 77$ & $31 / 39$ \\
\cline { 2 - 5 } & $\mathrm{H}(\mathrm{n}=38)$ & $3 / 8$ & $27 / 71$ & $16 / 42$ \\
\cline { 2 - 5 } & $\mathrm{D}(\mathrm{n}=59)$ & $7 / 12$ & $48 / 81$ & $21 / 36$ \\
\hline \multirow{3}{*}{ Number/\% of farms } & $\mathrm{A}(\mathrm{n}=23)$ & $0 / 0$ & $19 / 83$ & $7 / 30$ \\
\cline { 2 - 5 } & $\mathrm{H}(\mathrm{n}=9)$ & $0 / 0$ & $7 / 78$ & $3 / 33$ \\
\cline { 2 - 5 } & $\mathrm{D}(\mathrm{n}=14)$ & $0 / 0$ & $13 / 93$ & $5 / 36$ \\
\hline
\end{tabular}




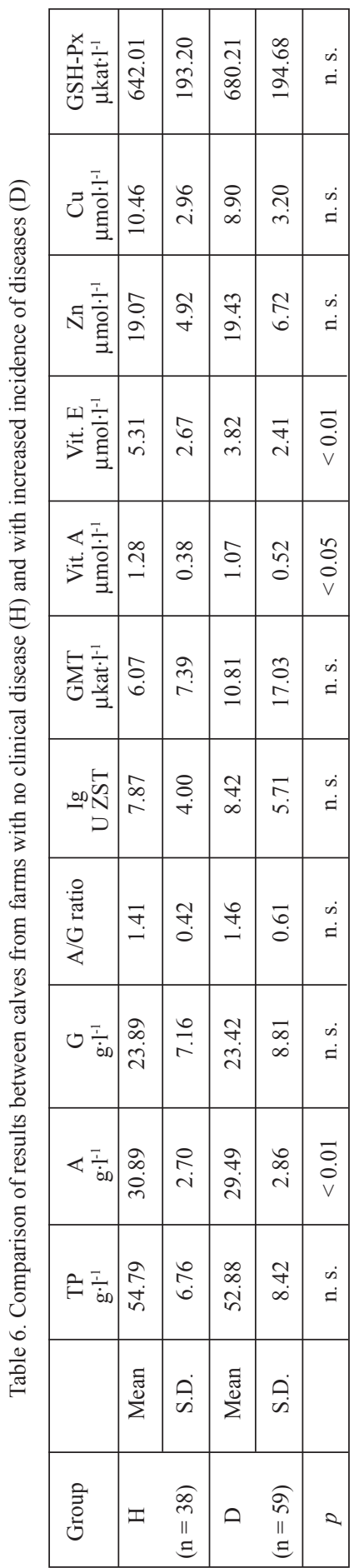

Tables 4 and 5 reveal clearly that there are no significant differences in the incidence of metabolic disorders diagnosed by laboratory methods between groups $\mathrm{H}$ and $\mathrm{D}$. With the exception of vitamins, $\mathrm{Zn}$ and $\mathrm{Cu}$, percentage occurrences of metabolic disorders are a little higher in group $\mathrm{H}$ of calves. These results prove a very high incidence of subclinical metabolic disorders even on calf farms with a low rate of disease.

Table 6 compares average values of individual monitored parameters between group $\mathrm{H}$ and $\mathrm{D}$ calves. In animals from farms with no clinical disease $(\mathrm{H})$ we established a significantly higher concentration of vitamin $\mathrm{A}(p<0.05)$, vitamin $\mathrm{E}(p<0.01)$ and albumin $(p<0.01)$. These higher concentrations of vitamins may represent one of the important factors that improve the immunity of calves and thus their health, because it is well known that vitamins positively influence the functions of the immune system (Politis et al. 1995; Chew 1995).

While examining 97 calves on 23 farms both displaying and not displaying clinical forms of the diseases, a high occurrence of metabolic disorders related to the colostral nutrition disorders and a high occurrence of microelement deficiencies were found. Some metabolic disorders were detected on all of the monitored farms.

The results presented in the tables show that the assumption can be confirmed that after colostrum intake the increase in immunoglobulin count causes not only an increase in their concentration, and with it a rise in the concentration of TP and a fall in the $\mathrm{A} / \mathrm{G}$ ratio, but that there is a significant increase in the catalytic activity of GMT in the serum of the calves, itself reaching high levels of concentration in the colostrum (Bogin et al. 1993; Lombardi et al. 2001). In spite of the fact that the correlations of the GMT activity on one part and other parameters on the other are not absolutely close (Pavlata et al. 2003a), GMT activity monitoring can be used with a relative reliability to check whether the calf was fed colostrum or not and also to determine the assumed immunoglobulin concentration. However, the GMT values can be used to check colostral nutrition of the calf only in the periods of colostral and early milk nutrition because its activity decreases in older calves, or more precisely, it re-establishes its low physiological level.

When assessing the parameters related to colostral nutrition, we found a majority of the calves to be hypoproteinic, hypoglobulinic, with decreased concentration of immunoglobulins and low GMT activities which stands proof of insufficient colostral nutrition of the calves. We also detected a high percentage of hypovitaminosis E.

Nevertheless, it is clear that colostrum is an essential 


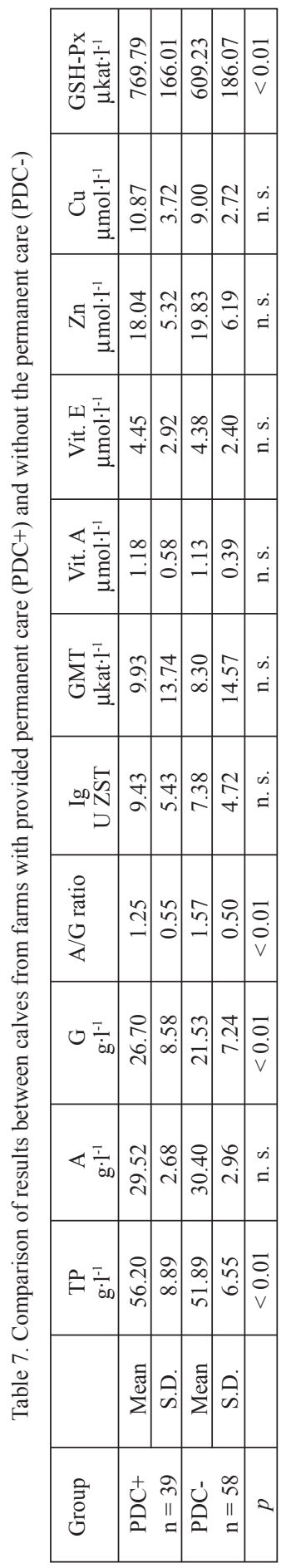

source of fat-soluble vitamins; in calves during colostral nutrition we previously found (Pavlata at al. 2005a) only a loose correlation between the concentration of the vitamin $\mathrm{A}$ and TP and the concentration of the vitamin E and GMT activity. Correlations between other biochemical indicators and vitamin concentrations were not found at all (Pavlata at al. 2005a). Vitamin concentrations in the serum of calves are certainly subject to a series of other factors, e.g. their colostral contents. If there is a low concentration already in the dam and thus in its colostrum, then even a sufficient colostral intake cannot be enough to establish physiological levels in calves. Additionally, no relation between the concentration of vitamin $\mathrm{E}$ in serum of the dam and its concentration in colostrum was determined (Pavlata et al. 2004c). A very high incidence of hypovitaminosis $\mathrm{E}(77.7 \%)$ in calves of dairy cows during milk nutrition was identified in previous study, too (Pavlata et al. 2005b).

It may thus be said that the quality of colostral nutrition was insufficient in most of the herds. This condition can be clearly put in relation with insufficient care in the postpartum period. A majority of the farms nowadays have no continuous care and the calves are not fed colostrum early enough and sufficiently. This is an important factor, weakening the natural immunity mechanisms and creating space in calves for pathogens to gain hold and infectious diseases to set in. The importance of the provision of permanent day and night care during deliveries and in the early postpartum period is shown by the results in Table 7.

When comparing average values of individual indicators between calves from farms with permanent care $(\mathrm{PDC}+)$ and without permanent care (PDC-), there is a clear trend towards better results of colostral nutrition quality test in calves from the PDC+ group. In this group, we established higher average values of almost all parameters influenced by colostrum intake (TP, G, Ig, GMT, vitamins). Statistically significant differences $(p<0.01)$ between PDC + and PDC-groups were proven in TP, $\mathrm{G}$ concentration, and in the $\mathrm{A} / \mathrm{G}$ ratio. These results prove that permanent care brings about better results in colostral nutrition, because e.g. early administration of a sufficient amount of quality colostrum, which is only possible in the PDC+ system, is a key factor for an adequate intake of colostrum.

The significant difference in the GSH-Px activity among $\mathrm{PDC}+$ and PDC-groups is probably not directly related to the care, because the GSH-Px activity is an index of long-term supplementation of organism with selenium, and depends mainly on the supplementation of the cows with selenium during gravidity (Pavlata et al. 2003b), or on the interaction with other elements that may influence the selenium status (Pavlata et al. 2005c).

Results of microelement metabolism show that deficiencies in copper and selenium were noted frequently. On the other 
hand, zinc deficiency in calves was noted very rarely. Given the fact that microelements enter the foetus in the course of the intrauterine development, it is necessary to pay attention to the supply with microelements already in pregnant cows. Major differences between the parameters of the micromineral metabolism in the mother/young relationship described Pavlata et al. (2003b, 2004b, and 2005d). The calf organism can accumulate zinc throughout the intrauterine development and zinc is cumulated in cow colostrum, but serum copper concentration of newborn calves is significantly lower compared with the mothers and colostrum copper concentrations reach just about $60 \%$ of serum copper concentrations of the cows. Although blood copper concentration of calves increases throughout the period of colostral nutrition, it does not reach the level of serum copper concentration of the mother by the end of the period. The selenium status of newborn calves is similar to that of the mother cows and as with copper, selenium is not cumulated in colostrum to any significant extent.

The key causes of the diagnosed subclinical metabolic disorders are thus to be seen in unsatisfactory care, low quality colostral nutrition of the calves and microelement deficiencies displayed already in pregnant cows. The results prove the necessity of providing permanent care for calves in the early postpartum period, which is the precondition for the improving of the quality of colostral nutrition. Very high occurrence of subclinical metabolic disorders in calves from farms with no clinical disease proves a high potential risk of clinical diseases in calves that are pre-disposed to the occurrence of metabolic disorders.

\section{Poruchy metabolismu u telat mléčného skotu v poporodním období}

Cílem práce bylo $\mathrm{v}$ rámci analýzy př́icin vzniku onemocnění telat $\mathrm{v}$ chovech mléčného skotu vyhodnotit výskyt poruch metabolismu telat v postpartálním období. Ve 23 zemědělských podnicích (14 chovů s výskytem klinických forem onemocnění u telat v období mléčné výživy - skupina $\mathrm{D} ; 9$ chovů bez př́znaků klinických forem onemocnění - skupina $\mathrm{H}$ ) bylo u telat $\mathrm{v}$ období mléčné výživy provedeno klinické vyšetření, odběr vzorků $\mathrm{k}$ laboratornímu vyšetření a zjištěny údaje o zajištění trvalé denní i noční ošetřovatelské péče (PDC) o telata při porodu a $\mathrm{v}$ časném poporodním období. Vzorky byly odebrány vždy od 3 - 5 telat v jednom chovu (celkem 97, H - 38, D - 59). U telat byly vyšetřeny parametry mající vztah ke kvalitě kolostrální výživy (koncentrace imunoglobulinů - Ig, celkové bílkoviny - $\mathrm{CB}$, albuminů - A, globulinů - G, vitaminu E a A a aktivita gamaglutamyltransferázy - GMT) a hodnotící mikrominerální metabolismus (aktivita GSH-Px pro hodnocení stavu zásobení zvírat selenem, koncentrace mědi a zinku).

Při vyhodnocení celého souboru vyšetřených telat byl zjištěn vysoký výskyt poruch metabolismu souvisejících s poruchami kolostrální výživy a také vysoký výskyt mikrominerálních karencí. U 80 \% vyšetř̌ených telat byla zjištěna snížená koncentrace $\mathrm{CB}$, u 78 \% telat snížená koncentrace globulinů, u 78 \% snížená koncentrace Ig a u 74 \% zvýšený poměr albuminů a globulinů. U $76 \%$ byla také nízká aktivita GMT dokladující nedostatečné napojení kolostrem. U $67 \%$ vyšetřených telat byla diagnostikována hypovitaminóza E a u 19 \% telat hypovitaminóza A. Snížené hodnoty Cu byly zjištěny u $77 \%$ telat, karence selenu u $39 \%$ a deficit Zn u $10 \%$ telat. Při porovnání výsledků $\mathrm{u}$ telat skupiny $\mathrm{H}$ a $\mathrm{D}$ byly ve skupině telat pocházejících z chovů klinicky zdravých (H) zjištěny průkazně vyšší $(p<0,01)$ koncentrace albuminu a vitaminu $\mathrm{E}$ a také vitaminu A $(p<0,05)$. Při porovnání chovů se zajištěnou celodenní ošetřovatelskou péčí $(\mathrm{PDC}+)$ a bez celodenní péče ( $\mathrm{PDC}-)$, byla u telat $\mathrm{z}$ chovů $\mathrm{PDC}+$ zjištěna průkazně vyšší $(p<0,01)$ koncentrace TP a G, aktivita GSH-Px a také průkazně nižší $(p<0,01)$ 
poměr A/G, což dokladuje kvalitnější kolostrální výživu telat. Výsledky dokazují, že výskyt poruch metabolismu je u telat mléčných plemen v ČR velmi aktuálním problémem a že jedním z významných faktorů ovlivňujících tento stav je nedostatečná ošetřovatelská péče a s tím související neplnohodnotná kolostrální výživa telat.

\section{Acknowledgement}

The work was supported by the Research Project of the Ministry of Education, Youth, and Sports No. MSM6215712403.

\section{References}

ABDELRAHMAN MM, KINCAID RL 1993: Deposition of copper, manganese, zinc, and selenium in bovine fetal tissue at different stages of gestation. J Dairy Sci 76: 3588-3593

BLUM JW, HAMMON H 2000: Colostrum effects on the gastrointestinal tract, and on nutritional, endocrine and metabolic parameters in neonatal calves. Livest Prod Sci 66: 151-159

BOGIN E, AVIDAR Y, SHENKLER S, ISRAELI BA, SPIEGEL N, COHEN R 1993: A rapid field test for the determination of colostral ingestion by calves, based on gamma-glutamyltransferase. Eur J Clin Chem Clin Biochem 31: 695-699

BOUDA J, JAGOŠ P, DVOŘÁK V 1980: Fluorometric determination of vitamins A and E in blood plasma, colostrum and in the liver of cattle. Cs Fysiol 29: 351

CAMPANA WM, BAUMRUCKER CR 1995: Hormones and growth factors in bovine milk. In: JENSEN RG (Ed.): Handbook of Milk Composition, Academic Press, San Diego, pp. 476-494

HOFÍREK B et al (Ed.) 1990: Animal Diseases Diagnostics and Prevention - II. Diseases of cattle (in Czech), Vysoká škola veterinární, Brno, 358 p.

HOSTETLER CE, KINCAID RL, MIRANDO MA 2003: The role of essential trace elements in embryonic and fetal development in livestock. Vet J 166: 125-139

CHEW BP 1995: Antioxidant vitamins affect food animal immunity and health. J Nutr 125: S1804-S1808

KRAFT W, DÜRR U 2001: Clinical Laboratory Diagnostics in Veterinary Medicine (in Slovak), Hajko \& Hajková, Bratislava, 365 p.

LOMBARDI P, AVALLONE L, PAGNINI U, D’ANGELO D, BOGIN E 2001: Evaluation of buffalo colostrum quality by estimation of enzyme activity levels. J Food Protect 64: 1265-1267

PAVLATA L, CHOMÁT P, HALOUN T, PODHORSKÝ A, PECHOVÁ A 2003a: An analysis of the causes underlying the increased morbidity in calves (in Czech). Project report FRVŠ, $30 \mathrm{p}$.

PAVLATA L, PECHOVÁ A, DVOŘÁK R, PODHORSKY A, LOKAJOVÁ E 2004a: Comparison of biochemical profiles of blood of cows, their calves in the day of birth and calves at the end of the colostral period. In: The effect of herd health of cattle, sheep and goat on production efficiency. The $5^{\text {th }}$ Middle-European Buiatrics Congress, Hajdúszoboszló, Hungary, pp. 375-380.

PAVLATA L, PECHOVÁ A, DVORÁK R 2004b: Microelements in colostrum and blood of cows and their calves during colostral nutrition. Acta Vet Brno 73: 421-429

PAVLATA L, PECHOVÁ A, ILLEK J 2000: Direct and indirect assessment of selenium status in cattle - a comparison. Acta Vet Brno 69: 281-287

PAVLATA L, PODHORSKÝ A, PECHOVÁ A, DVOŘÁK R 2005a: Metabolic disorders of calves in postpartum period. In: MALINOWSKI E, BEDNAREK D (Eds.): Achievements and Prospects of Ruminants Medicine, Polish Association for Buiatrics, Pulawy, pp. 125-130.

PAVLATA L, PODHORSKÝ A, PECHOVA,A, DVOŘÁK R 2005b: Incidence of hypovitaminosis E in calves and therapeutic remedy by selenium-vitamin supplementation. Acta Vet Brno 74: 209-216

PAVLATA L, PODHORSKYY A, PECHOVÁ A, CHOMÁT P 2005d: Differences in the occurrence of selenium, copper and zinc deficiencies in dairy cows, calves, heifers and bulls. Vet Med - Czech 50: 390-400

PAVLATA L, PRÁŠEK J, FILÍPEK J, PECHOVÁ A 2004c: Influence of parenteral administration of selenium and vitamin E during pregnancy on selected metabolic parameters and colostrum quality in dairy cows at parturition. Vet Med - Czech 49: 149-155

PAVLATA L, PRÁŠEK J, PODHORSKÝ A, PECHOVÁ A, HALOUN T 2003b: Selenium metabolism in cattle: maternal transfer of selenium to newborn calves at different selenium concentrations in dams. Acta Vet Brno 72: 639-646

PAVLATA L, ŠLOSÁRKOVÁ S, FLEISCHER P, PECHOVÁ A 2005c: Effects of increased iodine supply on the selenium status of kids. Vet Med - Czech 50: 186-194

PECHOVÁ A, PAVLATA L, ILLEK J 2005: Blood and tissue selenium determination by hydride generation atomic absorption spectrophotometry. Acta Vet Brno 74: 483-490

POLITIS I, HIDIROGLOU M, BATRA TR, GILMORE JA, GOREWIT RC, SCHERF H 1995: Effects of vitamin E on immune function of dairy cows. Am J Vet Res 56: 179-184

RAUPRICH ABE, HAMMON HM, BLUM JW 2000: Influence of feeding different amounts of first colostrum on metabolic, endocrine, and health status and on growth performance in neonatal calves. J Anim Sci 78: 896-908 
SLANINA L et al (Ed.) 1991: Health and Production of Calves (in Slovak). Príroda, Bratislava, 387 p.

SLANINA L, VAJDA V, BLAŽEJ J 1976: Turbidimetric analysis of immunoglobulins in calves and their clinical evaluation. Veterinářství 9: 392-394 